4. Özsoylu S, Allahverdi H, Laleli Y, Pirnar A. Platelet survival in childhood idiopathic thrombocytopenic purpura in remission. J Pediatr 1976;89:388-390.

5. Özsoylu \$̧, Karabent A, Irken G, Tuncer M. Antiplatelet antibody in childhood idiopathic thrombocytopenic purpura. Am J Hematol 1991;36:82-85.

6. Özsoylu \$̧, Ertürk G. Oral megadose methylprednisolone for acute childhood idiopathic thrombocytopenic purpura. Blood 1991;77:1856-1857.

7. Özsoylu \$̧. Megadose methylprednisolone for childhood idiopathic thrombocytopenic purpura (ITP). Turk J Med Sci 2005;35:347-356.

8. Engin E, Kılınç Ö, Ozsoylu Ş. Sağlık personelinin serum fizyolojik ile üst solunum yolları enfeksiyonlarından korunması. Yeni Tip Dergisi 1997;14:211-212.

9. Simpson KN, Coughlin CM, Eron J, Bussel JB. Idiopathic thrombocytopenia purpura: treatment patterns and an analysis of cost associated with intravenous immunoglobulin and anti-D therapy. Semin Hematol 1998;35(Suppl 1):5864.

10. Blackhouse G, Xie F, Levine MA, Campbell K, Assasi N, Gaebel K, O'Reilly D, Tarride J, Goeree R. Canadian costutility analysis of intravenous immunoglobulin for acute childhood idiopathic thrombocytopenic purpura. J Popul Ther Clin Pharmacol 2012;19:e166-178.

11. O'Brien SH, Ritchey AK, Smith KJ. A cost-utility analysis of treatment for acute childhood idiopathic thrombocytopenic purpura (ITP). Pediatr Blood Cancer 2007;48:173-180.

Address for Correspondence: Ali AYÇiÇEK, M.D.,

Kanuni Sultan Süleyman Research and Education Hospital, Clinic of Pediatric Hematology/ Oncology, İstanbul, Turkey

E-mail: ayciceka@hotmail.com

Received/Geliş tarihi: November 07, 2014

Accepted/Kabul tarihi: December 02, 2014

DOI: $10.4274 /$ tjh.2014.0436

\section{Gaucher Disease and Gaucher Cells}

\section{Gaucher Hastalı̆̆ ve Gaucher Hücreleri}

\section{To the Editor,}

I read the paper entitled "Gaucher cells or pseudoGaucher cells: that's the question" written by Gören Şahin et al. in a recent issue of this journal. The authors mentioned the main findings of Gaucher cells and pseudo-Gaucher cells in their article without calling attention to the lysosomal enzyme $\beta$-glucocerebrosidase levels [1].

Gaucher disease is inherited as an autosomal recessive disorder resulting from mutations at the glucocerebrosidase locus on chromosome 1q21. In this disorder, glucosylceramide (glucocerebroside) is stored in the reticuloendothelial system due to a deficiency of the lysosomal enzyme $\beta$-glucocerebrosidase [2]. The storage and deposition of

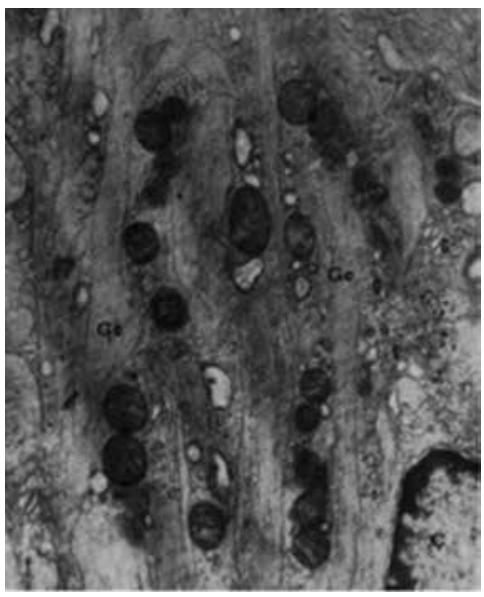

Figure 1. Electron micrograph of a Gaucher cell in the liver. In the cytoplasm, large Gaucher bodies containing tubular elements (25,000 , Gc: Gaucher bodies, Ç: nucleus, G: Golgi apparatus).

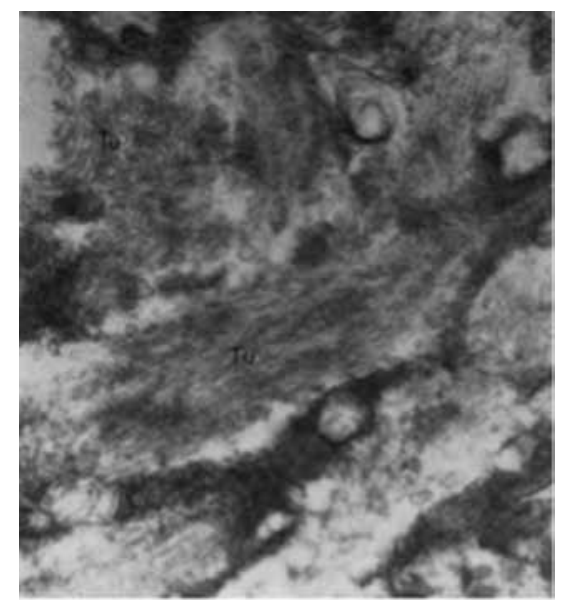

Figure 2. The cytoplasm of a Gaucher cell showed cytoplasmic bodies containing elongated tubular structures $\left(72,000^{\mathrm{x}}, \mathrm{Tu}\right.$ : tubules).

glucocerebroside within these cells, prominently macrophages, results in the appearance of Gaucher cells, which are very large cells with a diameter of 20-80 $\mu \mathrm{m}$, round or polyhedral. Gaucher cells have small, usually eccentrically placed nuclei and cytoplasm with characteristic wrinkles or striations. Electron microscopy reveals that the cytoplasm contains spindle or rod-shaped membrane-bound inclusion bodies of 0.6-4 $\mu \mathrm{m}$ in diameter consisting of numerous small tubules of 13-75 $\mathrm{nm}$ in diameter. Electron microscopy allows the identification of all stages of formation of the inclusions $[3,4]$.

Five patients were diagnosed with Gaucher disease by the presence of many Gaucher cells in the bone marrow associated with organomegaly and cytopenias between 1964 and 1970 in our department at Ankara University. Liver biopsy was performed in one of these patients and electron microscopic study was done. Ultrastructural analysis revealed many Gaucher bodies filled with tubules 
in the cytoplasms of Gaucher cells. These cells appeared as modified Kupffer cells by the accumulation in the cytoplasm of the cerebroside tubular material (Figures 1 and 2) $[5,6]$.

While Gaucher cells are a hallmark of the disease, the appearance of these cells in the bone marrow is not pathognomonic because pseudo-Gaucher cells have been described in several other hematologic disorders including chronic granulocytic leukemia, Hodgkin's disease, multiple myeloma, and AIDS [4,7]. Zidar et al. reported pseudoGaucher cells in the bone marrow of a patient with Hodgkin's disease. The patient's peripheral blood leukocyte $\beta$-glucosidase and serum acid phosphatase levels were elevated, and after 6 cycles of systemic chemotherapy, all signs of Hodgkin's disease and pseudo-Gaucher cells disappeared [8]. The presence of pseudo-Gaucher cells can pose a diagnostic challenge. In this respect, it is of crucial importance to demonstrate enzymatic deficiency for the diagnosis of Gaucher disease [7].

\section{Conflict of Interest Statement}

The author of this paper has no conflict of interest, including specific financial interests, relationships, and/ or affiliations relevant to the subject matter or materials included in this manuscript.

Key Words: Gaucher cells, Electron microscopy

Anahtar Sözcükler: Gaucher hücreleri, Elektron mikroskopi Sevgi Gözdaşoğlu

Retired Professor of Pediatric Hematology and Oncology, Ankara, Turkey

\section{References}

1. Gören Şahin D, Teke HÜ, Karagülle M, Andıç N, Gündüz E, Işıksoy S, Akay OM. Gaucher cells or pseudo-Gaucher cells: that's the question. Turk J Hematol 2014;31:428-429.

2. Kolodny EH, Charria-Ortiz G. Storage diseases of the reticuloendothelial system. In: Nathan DG, Orkin SH, Ginsburg D, Look AT (eds), Nathan and Oski's Hematology of Infancy and Childhood. Philadelphia, W.B. Saunders Company, 2003.

3. Bessis M. Blood Smears Reinterpreted. Berlin, SpringerVerlag, 1977.

4. Beutler E. Monocyte and macrophage disorders: lipid storage disease. In: Williams WJ, Beutler E, Erslev AJ, Lichtman MA (eds). Hematology. New York, McGraw-Hill Publishing Company, 1990.

5. Çavdar AO, Gözdaşoğlu S, Arcasoy A, Örs Ü, Kerse İ. Gaucher Hastalığı. A.Ü. Tıp Fakültesi Mecmuası 1972; XXV (Suppl 53).

6. Örs Ü, Kerse İ, Gözdaşoğlu S, Çavdar AO. Bir Gaucher Hastalığı Vak'asının Karaciğer İnce Yapısı. Çocuk Sağlığı ve Hastalıkları Dergisi 1971;14:109-131.
7. Weinreb NJ. Pathophysiology, clinical features and natural history of Gaucher disease. Clin Adv Hematol Oncol 2012;10:3-6.

8. Zidar BL, Hartsock RJ, Lee RE, Glew RH, LaMarco KL, Pugh RP, Raju RN, Shackney SE. Pseudo-Gaucher cells in the bone marrow of a patient with Hodgkin's disease. Am J Clin Pathol 1987;87:533-536.

Address for Correspondence: Sevgi GÖZDAŞOĞLU, M.D.,

Retired Professor of Pediatric Hematology and Oncology, Ankara, Turkey

Phone: +90 3124478046 E-mail: sgozdasoglu@hotmail.com

Received/Geliş tarihi: January 27, 2015

Accepted/Kabul tarihi: January 23, 2015

DOI: 10.4274/tjh.2015.0043

Reply:

We read the recent letter by S. Gözdaşoğlu regarding our manuscript with great interest. We would like to thank the author for bringing lysosomal enzyme $\beta$-glucocerebrosidase levels into attention. We absolutely agree that Gaucher cells in the bone marrow is not pathognomonic for Gaucher disesase, since several hematological malignancies can present with pseudo-Gaucher cells in the bone marrow, like in our case report. Therefore, studying leukocyte $\beta$-glucosidase levels is very important in differential diagnosis. In our case, we did not study this enzyme level because the patient age, the presence of $\mathrm{M}$ band in serum electrophoresis and the presence of lytic bone lesions in the skull made the multiple myeloma diagnosis straightforward. However, we went through the published literature once again in this regard and realized that there were only about 50 articles published about pseudo-Gaucher cells. In few of them leukocyte $\beta$-glucosidase enzyme levels were reported $[1,2]$. When we reviewed these papers, we saw that these enzyme levels can change according to homozygosity or heterozygosity of the disease. Heterozygotes showed intermediate levels of enzyme activity. In a study by Pentchev et al. [1] enzyme activity was about $15 \%$ of normal in the adult nonneurologic form (type 1) and about $2.3 \%$ in the neurologic forms (types 2 and 3). The authors concluded that all 3 forms of Gaucher disease result from a structurally mutated enzyme with altered catalytic efficiency. Taken together, leukocyte $\beta$-glucosidase enzyme level is critical in the differential diagnosis of pseudo-Gaucher cell dilemma cases.

Olga Meltem Akay

\section{References}

1. Pentchev PG, Neumeyer B, Svennerholm L, Groth CG, Brady RO. Immunological and catalytic quantitation of splenic glucocerebrosidase from the three clinical forms of Gaucher disease. Am J Hum Genet 1983;35:621-628.

2. Zidar BL, Hartsock RJ, Lee RE, Glew RH, La Marko KL, Pugh RP, Raju RN, Shackneys E. Pseudo-Gaucher cells in the bone marrow of a patient with Hodgkin's disease. Am J Clin Pathol 1987;87:533-536. 